\title{
GEOGRAFÍA LITERARIA EN LA PRENSA ROMÁNTICA: LA CUEVA ENCANTADA
}

\author{
Pilar VEGA RODRÍGUEZ \\ pvegarod@ccinf.ucm.es \\ Universidad Complutense
}

\section{Resumen}

Este trabajo examina el tópico de la cueva encantada en las noticias y leyendas literarias de tema geográfico publicadas en la prensa romántica. El motivo analizado se articula en torno a dos tipos principales: la cueva de la Encantada y la cueva de los encantos. Ambos siguen un camino similar, pero mientras el primero desarrolla leyendas literarias el otro, cuyo tipo más conocido es la cueva de Hércules, produce en el periodismo romántico, principalmente, el debate y la polémica.

Palabras clave: Geografía literaria, Leyendas, Cueva encantada, Revistas románticas, Cueva de Hércules.

\begin{abstract}
This paper focuses on literary motif of haunted cave palace in romantic legends published in journals. In this issue two types can be considered: the cave of fairy and the cave of spells. Both follow a similar path but while one developed literary legends the other one, whose most famous type is the cave of Hercules, sparked controversy and discussion in romantic journalism.
\end{abstract}

Keywords: Legends, Geography, Haunted Cave, Romantic reviews, Cave of Hercules.

\section{Lugares primordiales: la geografía como fuente de fabulación}

La representación literaria de espacios, paisajes y sitios culturales (Jouve, 1997; Lévy, 2006; Frank, 2009, 64-68; Piatti, 2009) y, a la inversa, la lectura literaria de los mismos (Nepveu, 2005; Lahaie, 2008) es hoy uno de los campos de investigación más interesantes de la Literatura Comparada. En estas 
páginas nos ocuparemos de analizar el espacio primordial de la cueva desde la perspectiva en que es leído por las leyendas literarias del Romanticismo español. Dicha lectura se apoya en la simbolización natural —la cueva siempre ha sido el lugar de la revelación del vaticinio o de la aparición maravillosa-a la que se añade la significación histórica de los marcos referenciales y las particularidades de los espacios de la narración y del universo narrativo (Ryan, 2009). Todos ellos impulsan la generación de la intriga (Brosseau 1996: 84 et 87) en cuanto que el acceso a la cueva, como lugar de la manifestación de lo sagrado, suele ser impedido u obstaculizado, de modo que el cruce umbral (la transgresión) - el recorrido espacial, en definitiva - constituye el motor del desarrollo narrativo.

Los textos analizados aquí proceden de la pesquisa de un legendario geográfico conformado por las leyendas literarias publicadas en la prensa española entre 1830 y 1870, amplificadas en muchos casos por sus autores en narraciones más extensas que fueron publicadas como capítulos de misceláneas, novelas o libros de viaje. Como es sabido, la prensa romántica española reservó un espacio considerable a la publicación de leyendas literarias, género que se presentaba entonces como innovación en el marco de la poesía narrativa, y en las que solía trabarse lo histórico y lo geográfico. La leyenda geográfica explicaba el origen y formación del paisaje familiar y le confería significación trascendente al presuponer que el espacio cercano había sido escenario de hechos prodigiosos bien conocidos por los naturales de un lugar. Generalmente estas leyendas basaron su narración en una lectura del paisaje a la que sumaban datos específicos sobre personajes históricos, bien conocidos para el público que las recibía. Por eso muchas de las leyendas literarias de tema geográfico son también leyendas con un marco histórico. Será este el caso de la famosa leyenda de la Cueva de Hércules, asunto principal de este trabajo, tan relacionada con la explicación del ocaso de la monarquía visigótica en España. Además de una justificación histórica esta leyenda ejemplifica uno de los dos modos de aparición del cronotopo primordial de la cueva encantada (Bahktine, 1978), la cueva de los encantos, por contraposición a la cueva de la Encantada. Éste último será el motivo predilecto de las leyendas literarias publicadas en prensa mientras que el tema de la cueva de los encantos, de Salamanca, de Montesinos, o de Hércules, como se dirá después, se convierte en objeto preferente de la polémica o la discusión arqueológica.

Pero antes de iniciar el examen del motivo de la cueva encantada conviene hacer notar su estrecha vinculación con el del edificio-palacio encantado-clausurado. En primer lugar, porque la cueva también puede ser obra arquitectónica, si recibe una acomodación artificial (por medios mecánicos o remedios 
mágicos); secundariamente, porque entre la cueva y el palacio puede existir una relación metonímica - en cuanto el palacio encantado es ignoto y misterioso, y pocas cosas hay más representativas de ese misterio oculto que sus criptas o cámaras subterráneas- pero también, porque la cueva, morada de seres extraordinarios, ha podido surgir tras la demolición del palacio, es decir, formando parte de él como sótano subterráneo o derramándose en secretos pasadizos hasta comunicar con el edificio. Por otra parte, cueva y palacio encantados configuran un cronotopo secundario, específico de la narración fantástica, que corporiza la interioridad psíquica oscura y tortuosa. Tanto la cueva de la Encantada como la cueva de los encantos son motivos que apuntan a recorridos y mapas situacionales de los personajes, del lugar encantado a la periferia, o al contrario, de la exterioridad al misterio clausurado.

\section{Etiología del paisaje: la cueva de la Encantada}

En las leyendas sobre la cueva de La Encantada la cueva-palacio se localiza fuera y a cierta distancia de la ciudad, su misterio es protegido por guardas visibles o invisibles (maleza y vegetación, un vapor fétido, corrientes de viento, humo y llamas, sonidos terribles, etc) y el acceso a ella es difícil y peligroso. Pueden servir de indicadores de la proximidad de lo maravilloso algunos signos emplazados en las inmediaciones de la cueva como ermitas, cementerios, castillos, etc. con un efecto generalmente maligno en el estado de cultivos, vegetación, o bienestar de hombres y ganados. En definitiva, la cueva es un lugar del que los naturales del país tienen buen cuidado en apartarse.

Todas estas circunstancias hacen de la cueva un lugar idóneo para buscar refugio, alcanzar la exclusión o administrar el castigo.

En los textos literarios que analizamos aquí La Encantada es el fantasma de una mujer (generalmente una doncella mora) presa en el encanto o maldición de la cueva a consecuencia de la muerte violenta (razón por la que su ánima aún busca la paz del sepulcro). La cueva es por tanto la habitación de un espectro ${ }^{1}$. La intriga de la leyenda se construye sobre el movimiento de

1. El motivo deriva de la creencia antigua en que las mujeres que acompañaban a los ejércitos árabes fueron abandonadas por sus compatriotas al marcharse éstos de la península. Aquellas mujeres se ocultaron en las cuevas de las montañas, al cuidado de los tesoros que los guerreros moros no pudieron llevarse y desde entonces, hace siglos, las «moras encantadas» viven en lo profundo de esas cuevas de donde jamás salen más que en noches de luna llena para buscar agua en las fuentes. A la mora encantada no se la puede ver más que un día al año, en la velada de S. Juan, corrobora un autor anónimo en La Floresta infantil: cuando sale «con sus doncellas de la gruta donde habita y <sólo> permanece fuera mientras peinan <sic> sus cabellos de oro». (8-12-1855, pág. 71). En definitiva, una mora más parecida a un hada nórdica que a una moura hispánica.

Anales, 25, 2013, pp. 397-427 
ingreso y de salida tanto del personaje principal, la Encantada, como de los co-actantes expresos o tácitos. El umbral es cruzado por la Encantada sin prohibición expresa, más aún, como posible liberación. De otra parte, la cueva es el escenario de la afrenta, persecución, violación y muerte en la que intervienen otros personajes (amantes despechados, correligionarios vengadores, enamorados) que ingresan en ella. Pero además, la cueva es contemplada desde la otra perspectiva, como frontera inquebrantable, para los que ven salir a la Encantada y no osan acercarse al espacio mágico.

El ejemplo literario más conocido de este motivo es la leyenda becqueriana «La cueva de mora» publicada en El Contemporáneo en 1863 y cuyo argumento plantea el trágico amor entre un cautivo cristiano y una mora, bautizada in extremis por su amante. La leyenda participa de los detalles característicos del motivo. En primer lugar, la tradición llega al narrador, tranquilo paseante, desde los labios de un lugareño y viene precedida por el rumor de que el espíritu de los dos amantes aún reside en la cueva. El espacio interior de la cueva es presentado así por la imaginación popular y permite un recorrido en doble dirección: mientras los lugareños evitan el acercamiento el narrador entra en la cueva por la reconstrucción de la historia. Es fama también que en la cueva de la Mora, sita a los pies de un castillo del que sólo quedan ruinas, yacen sepultados cuantiosos tesoros. La cueva responde pues a la caracterización mítica (Cirlot, 2004; 178). Es también un híbrido de naturaleza y construcción humana dado que se emplaza a cierta distancia del espacio comunitario y forma parte del castillo como soporte subterráneo. Como espacio maravilloso es de difícil acceso. De hecho, la apertura de la cueva depende de un resorte mecánico, una escalera que arranca de ella sube hasta el alcázar y un largo subterráneo la derrama hasta el valle. El relieve inexpugnable del entorno (poterna cegada, camino secreto) las ruinas y la maleza que la ocultan (boquerón abierto en la peña viva y medio oculto por frondosos y espesísimos matorrales) y la fama de historias intimidatorias de los que, intencional o fortuitamente, han entrado en ella la defienden de los intrusos ${ }^{2}$. En la leyenda de Bécquer los espíritus del cristiano y la mora han sido apresados en la cueva en castigo de su traición; de la mora por haber renegado de los suyos, del cristiano por haber lanzado a sus huestes a la batalla no por la fe de todos, sino por el amor de uno solo.

Un texto cercano temáticamente al de Bécquer, aunque de inverso sentido y sin fantasma encantado propiamente, es «La cueva del lagarto. Leyenda de

2. «— ¡Penetrar en la cueva de la Mora! —me dijo, como asombrado al oír mi pregunta—. ¿Quien había de atreverse? ¿No sabe usted que de esa sima sale todas las noches un ánima?» (Bécquer, 2008: pág. 326) 
la Edad Media» publicado por Fernando Mellado en el Museo de las Familias (1866). Como en el relato becqueriano, también Mellado deriva su leyenda de la tradición oral, «Tal es la tradición que oí no ha mucho en las márgenes del Genil, a una linda colona de los señores que al presente» (Mellado, 1866: pág.17) y emplaza la cueva fuera de la ciudad, en lo alto de una montaña. Cierra la cueva una gran piedra oculta por la maleza (las ramas impiden el paso por todas partes, la espesura hace casi impenetrable aquel agreste sitio). El contraste entre exterior e interior es completo ya que la caverna aparece transformada en laboratorio fáustico. En esta leyenda quien habita en la cueva es un mago que vaticinará al protagonista, Mored-Alid, tras la observación de las vísceras de un lagarto, la conversión a la fe cristiana y el matrimonio de Zulima, la joven a la que ama, con un cautivo cristiano. Más adelante, cuando Mored-Alid esté a punto de dar muerte a los enamorados, un horrible lagarto de ojos centelleantes aparecerá para defender a Zulima y Rui Lope. Al verlo (diminuta versión del dragón huido de los romances fantásticos) Mored-Alid recuerda la predicción, se pone de lado de los amantes, e invocando a la Virgen de los cristianos arremete contra sus propios compañeros. Al borde de la muerte Rui Lope lo bautiza. La suerte del guerrero árabe es a la vez recompensa (por su generosidad con los cristianos) y castigo (por haber entrado en la batalla no tanto por su fe como por el reconocimiento de Zulima)

Mellado introduce como variante de la leyenda el carácter orgulloso de Zulima, que rechaza a todos sus pretendientes sin dar razón de su despego. Con esto el autor parece dar a entender que Zulima espera al hombre de sus sueños (el cautivo Rui Lope); sin embargo, el detalle de la caracterización es un signo también de la evolución de la fórmula de la Encantada. La cueva ha sido por tradición un lugar privilegiado de la escuela nigromántica (Cacho Blecua, 1995) 3 ; por ello, en nuevas versiones, como la recogida por Francisco Martínez de la Rosa en su novela Isabel de Solís (1844, II, XLII), la negativa de la joven a contraer matrimonio se explica no ya por el anhelo del amor ideal sino por la ambición de un conocimiento prohibido, la ciencia mágica (en la que hace progresos debidamente instruida por un tutor). Semejante dedicación augura su transformación en sacerdotisa, sibila, maga.

Para su novela Martínez de la Rosa se sirve de una leyenda conocida en la zona de Montesclaros, también en Granada. La hija del rey Abdalaxis aventajaba en hermosura a todas las mujeres de su tiempo y quería también ser superior a todos los hombres también por su entendimiento. Para complacerla

3. En la cueva de Salamanca residió por un tiempo el marqués de Villena y ejerció cátedra y oficio nigromántico.

Anales, 25, 2013, pp. 397-427 
su padre hizo venir de Egipto a un sabio mago que la inició en la ciencia astrológica y la alquimia. Envanecida por sus triunfos la joven rechazaba a todos sus pretendientes hasta que llegó un momento en que el rey no pudo sino maldecir las aficiones de la princesa. Murió la joven, quizá a consecuencia de un error en sus artes mágicas, y su padre, avergonzado, la hizo enterrar en una cueva inaccesible. Desde entonces comenzó a aparecerse, precedida por el signo de la niebla, y a lamentarse con suspiros dolorosos que aterrorizaban a los rústicos. Convertida en hada hizo surgir el río de las mesas de Villaverde, modificó el relieve de los montes, labró las salas de la cueva y siempre se mostraba deseosa de lidiar con los caballeros como si fuese un fuerte varón. Como en los ejemplos anteriores la leyenda se propone como tradición del país y es referida por uno de los personajes, el guía, aprovechando un descanso del trayecto y antes de que la legendaria cueva se haga visible.

Es también la historia, más o menos, de «La cueva de la judía», relato de Froilán Carvajal y Rueda publicado en el Semanario pintoresco español (1857) y ambientado en Cuenca. El texto se enmarca no ya en un paseo turístico sino en el reconocimiento casi profesional de la cueva que da lugar al artículo publicado en el Semanario. La leyenda llega como colofón del reportaje a modo de narración recogida directamente de los «naturales del país» (1857: pág.181) con la que se puede explicar la historia del gran peñasco en que todavía quedan vestigios de una torre.

Si en este tipo de relatos es frecuente marcar la transición entre espacios interiores y exteriores de la cueva, dado que la boca de la cueva es puerta de entrada a una experiencia maravillosa, en el texto de Carvajal se expresa perfectamente este contraste sin recurrir a la presencia de personajes fantásticos. El acceso a la Cueva la Judía (extramuros de la ciudad) es dificultoso por lo resbaladizo y puntiagudo de las piedras del camino. El contraste entre la hostilidad del paisaje exterior, y la quietud, frialdad y belleza del interior de la cueva es severo, hasta el punto, dice Carvajal, de que hace experimentar el tránsito entre «los extremos más distantes: el de ser y el de no ser «(Carvajal, 1866: pág.179). A pocos metros de la entrada «se deja ver la cueva en toda su magnífica extensión, en toda su desmesurada altura y en toda su profundidad maravillosa y sorprendente; y todo varía de aspecto, todo cambia y se transforma de la manera más completa y absoluta» (ibid). Carvajal refiere la leyenda de un modo tan sucinto que apenas permite seguir la historia. Una muchacha pobre vive con sus padres a las afueras de la ciudad y tiene un pretendiente, pastor, que la visita de vez en cuando. En cierta ocasión le sorprende en el campo una terrible tormenta y tiene la desgracia de encontrarse con un rico caballero de la ciudad que también ha extraviado su camino. El 
caballero, hijo de uno de los grandes señores de la ciudad, comienza a visitarla desde aquella tarde y a cortejarla. Ella lo rechaza, sigue Carvajal: «Lo despreció, últimamente, y la perdió de la manera más completa. Había herido un orgullo que se creía invulnerable. De sus resultas, fue la infeliz deshonrada» (Carvajal, 1866: pág.182). Los padres de la muchacha mueren de pesar y ella se vuelve loca. Por esta razón comienza a deambular por las montañas donde «se estaba allí escondida días enteros». Su pretendiente, el pastor, sigue sus pasos y trata de cuidar de ella, hasta que un día la ve desaparecer por la hendidura de una cueva, de la que nunca más querrá salir y que, desde entonces, será llamada «La Cueva de la Judía».

El texto de Trinidad de Rojas ${ }^{4}$ «La cueva de Menga», publicado en el Museo Universal (1861), refiere la misma leyenda con más pormenor, esta vez haciendo protagonista de ella a la princesa Kelma, hija única de un príncipe siempre ausente, que vive recogida y ocupada en sus quehaceres. Una tarde que la joven pasea por el bosque estalla la tormenta y queda apresada en el incendio provocado por un rayo. La salva del fuego un joven al que conoce de hace tiempo y Kelma, embebecida después de la horrible experiencia, se deja seducir: «El vil seductor había desaparecido en los aires entre una nube de humo negro y pestilente, más negro que sus alas, menos hediondo que su aliento. Era el diablo» (Rojas, 1861: pág. 295) Para protegerla de la sentencia de muerte, el padre acude a un mago que le hace tomar unas yerbas por las que ella queda como muerta y es llorada y conducida a la cueva para su enterramiento. El mago cubre de piedras el lugar y hace crecer la vegetación para ocultar la entrada; pero traza un subterráneo que comunique la cueva con el palacio de su padre. A partir de ese momento padre e hija saldrán de noche al campo y se ocultarán de día.

Trinidad de Rojas menciona la leyenda como colofón de un artículo geográfico sobre la cueva de Menga en el que se especula sobre su utilización como necrópolis celta o templo druídico y se describen las últimas tentativas realizadas para su exploración: cuando se cerró la cueva con una puerta enrejada y dejó de buscarse la supuesta galería subterránea que habría conectado la cueva con un castillo árabe próximo. Rojas describe el emplazamiento de la cueva de Menga, sus materiales, textura, altitud, profundidad, puerta

4. Trinidad de Rojas, licenciado en Derecho y miembro de la academia literaria de Antequera, fue Diputado a Cortes por Málaga en 1864. La Cueva de Menga era un lugar peligroso porque más de una vez fue utilizado como refugio por los delincuentes: el 30 de septiembre de 1858 La Discusión daba la noticia del arresto en la cueva de Menga de una partida de forajidos $\left(\mathrm{n}^{\circ}{ }^{\circ} 799,2\right.$.) El Museo Universal sacó un grabado de la cueva en el n. 39 (22-septiembre de 1866).

Anales, 25, 2013, pp. 397-427 
de ingreso y habla del silencio pavoroso que reina en ella, no interrumpido más que por los cantos fúnebres que se escuchan en el cementerio colindante cuando se lleva a alguien a enterrar. Por su antiguo uso como necrópolis y por la vecindad del cementerio cristiano la cueva es como una especie de "palacio de la muerte», razón por la que quizá ha dado lugar a las «oscuras, supersticiosas y fantásticas consejas» que refieren las ancianas. Aunque añade Rojas irónicamente: «No hay en él, sin embargo, ningún gigante encantado, ningún alma en pena, ninguna bruja bailarina ni seres de tal especie que inspiren supersticioso miedo a los transeúntes» (Rojas, 1861: pág. 295).

Manuel Ibo Alfaro utiliza los mismos tópicos en su novela La mora encantada o la bandera de amor (1859, cp. IX) donde la cueva es escenario de varios episodios de amores contrariados y del anhelo del conocimiento prohibido 5 . Esta cueva es lo único que queda del antiguo baño de la Princesa Zara, asesinada por el judío mago Moisés Lobeid. El acceso a la cueva es dificultoso, los lugareños desconocen el punto exacto de ingreso pero, aunque escondida a la vista, la imaginación supersticiosa hace salir de ella una neblina blanca que precede a la aparición de la Encantada. La mora sale de la cueva en días de luna y deambula por los alrededores como una sombra blanca. De la cueva salen reflejos sulfurosos y rugidos como de tempestad. Otro elemento característico mencionado es el encarecimiento de la profundidad y peligrosidad de la cueva: «Aseguran también, que por este agujero sale una corriente de aire húmedo; y que si por dicho agujero se tiran piedras se oye un ruido ininterrumpido, que se debilita por grados, hasta perderse en la nada, cual si la piedra cayera por una escalinata sin fin» (Ibo Alfaro, 1859: pág. 27).

Insistiendo ahora en la vinculación entre palacio y cueva encantada la «Historia de Alarabi», publicada en 1858 en El Iris, muestra la comunicación entre ambos, también a través de subterráneos o galerías que enlazan los edificios. En esta leyenda tres caballeros entran en el palacio de Mohamad Alarabi amenazándole de muerte si no les entrega a su hija Zaida. Como él se niega lo arrojan al suelo para matarlo. Zaida acude en su defensa y apuñala a uno de los caballeros. En venganza, otro de ellos, Diego de Uceda, señor de Carpio, asesina al padre de Zaida y se lleva a la joven, que se ha desmayado, a su castillo. El sótano del castillo de Carpio es el lugar de la violación de Zaida mientras ella sigue inconsciente. Al despertar, la joven reconoce su desgracia y es presa de tal dolor y vergüenza que cae muerta. Lleno de horror, Uceda quiere huir del

5. Sobre esta leyenda escribió Manuel Ibo Alfaro el cuento «La Cueva de la Luna» que fue premiado con Diploma de honor de primera clase por la Academia Montreal de Francia en 1882. Lo publicó ese mismo año en La Ilustración de Barcelona, 30 de abril, págs.221-224 y 7 de mayo, págs.282-259. 
sótano del castillo pero siente que «flaquean sus piernas y una mano de bronce le sujeta» (El Iris, 1858: pág.4). Tratando de llamar en auxilio a sus criados quiere gritar, pero un nudo se le interpone en la garganta. «Empieza a ver fantasmas por do quiera. No oye sino lamentos y agonías. Solo se halla tranquilo cuando está al lado del cadáver. No parece sino que la justicia divina le impone como pena la contemplación de su crimen» (El Iris, 1858: pág.5) Por fin, Diego de Uceda se decide a enterrar a Zaida en el sótano del palacio. Un mes después el pueblo celebra un acto de conjuración de los espíritus diabólicos del palacio. La procesión de clérigos abre la mansión y topa con toda una caterva de demonios, sombras y espectros que organizan un estruendo horrible. Bandadas de búhos, cuervos y murciélagos revolotean por el edificio. Las culebras y serpientes salen de la profundidad de la tierra y todo el palacio se conmueve al resonar de tristes lamentos. El boquete realizado en la bóveda para entrar en el palacio es todo lo que hoy puede verse del castillo desparecido, es decir, el umbral de la cueva, conocida «bajo el nombre de la Encantada», continúa siendo defendido por los clásicos signos (hedor, gritos y corrientes de aire) 6 .

Como recapitulación de los ejemplos mostrados hasta el momento, en todos estos casos la fábula se construye a partir de la contemplación de huellas visibles en el paisaje: un boquerón en la roca, una hendidura en la montaña, una cueva con restos de alguna edificación. La simbolización natural de la cueva propicia la reconstrucción imaginativa. Una cueva es en cierto modo una especie de cápsula del tiempo. Por sus condiciones de aislamiento, temperatura, oscuridad, y por las prácticas culturales asociadas a ella, la cueva es el símbolo de lo primordial, telúrico e iniciático. La cueva es el lugar del nacimiento, del origen, de las fuerzas irracionales: una especie de vientre subterráneo. A partir de esta comprensión del espacio la trama de estas leyendas construye la historia del ultraje de una doncella o de la consumación feliz de

6. Una variante del relato es el texto de Fernando Mellado, «La cueva de la mora», publicado en el Museo de las Familias en 1870. Sobehia se niega a aceptar a su pretendiente Al-Mohadet, quien la secuestra. En el camino hacia el palacio del moro Sobehia logra zafarse y encuentra la puerta oculta de una cueva por la que ingresa sin vacilar a pesar de la oscuridad profunda. Al-Mohadet trata de seguirla, pero un terror supersticioso le impide pasar del umbral de la cueva, por lo que decide hacer guardia en la boca de la cueva hasta que la joven no tenga más remedio que salir muerta de hambre. Pero Sobehia se interna por las galerías de la cueva y andando a oscuras llega al palacio de los cristianos. Sin saberlo la mora ha cogido el pasadizo construido para desembocar directamente en el campo. El fruto de esta expedición es su encuentro con Rodrigo, de quien se enamora, y su conversión al catolicismo: «La cueva por donde milagrosamente se salvó Sobehia, se llamó desde entonces Cueva de la Mora, nombre que aún conserva el agujero ruinoso que se distingue cerca del rio Guadarrama, y no lejos de Villa viciosa» concluye el autor (Museo de las Familias, 1-4-1870, pág. 151)

Anales, 25, 2013, pp. 397-427 
un matrimonio. También coinciden los relatos examinados en otros puntos, la ubicación de la cueva fuera de la ciudad, a veces bajo las ruinas de un castillo; su difícil acceso; la actitud escéptica de los narradores, que salvan la incredulidad del lector atribuyendo lo narrado a la tradición popular; la sugerencia del tesoro y el guardián del umbral, que implican prohibición y delito; el topónimo otorgado a la cueva, derivado de su huésped (mora, judía, lagarto). En definitiva, construyendo el espacio el relato se construye a sí mismo (Lévy, 2006:3). Los recorridos y pasos de umbral del narrador y personajes tejen la intriga: el ingreso en la cueva de la doncella, de donde saldrá únicamente como encantada; la entrada en la cueva del narrador, para cubrir el resto de lo imaginado a medias por los naturales del lugar; la defensa del umbral por parte de los guardianes, etc.

Prueba de que estas leyendas han generado un set de características narrativas que pueden ser reutilizadas a voluntad es su empleo en relatos que nada tienen que ver con el tópico de la casa cerrada y encantada, como en el cuento de Manuel del Palacio «La cueva de Zampoña» (1857). Esta cueva de las cercanías de Soria, denominada de la Encantada y protegida por la superstición, no es morada de seres mágicos sino el escenario de turbios negocios; pero inspira el horror tradicional, de ahí que pueda alcanzar el recato necesario para la comisión del crimen. «Era cosa corriente entre el pueblo, y probablemente lo será todavía — aclara Palacio— que llegada la noche oíanse salir de aquel abismo lamentos, gritos y maldiciones, mezclado todo con un ruido tal de cadenas que atemorizaba al más osado y emprendedor» (Palacio, 1857: 47). El marco tradicional de la leyenda geográfica sirve aquí para narrar un suceso histórico, la muerte de Garcilaso de la Vega a manos de Bertrán Núñez para vengar a su padre, el zapatero de Zampoña. En la cueva encontrará Beltrán el tesoro, cofres de oro y joyas, y el expolio máximo, el cadáver de su padre sobre los sacos de doblones. Junto a él un pergamino con la advertencia clásica, «El que en esta cueva entrare / ni vivo ni muerto sale» (ibid.) ${ }^{7}$.

Los elementos analizados hasta ahora se toman como referentes tópicos de la construcción de otros relatos con mayores pretensiones literarias según veremos a continuación.

7. Lo mismo puede decirse de la leyenda de La Cueva del Amor, ambientada en Biarritz, escenario del final trágico de Sara, pescatera del mercado de Bayona, y Lorenzo, hijo de un labrador. La familia de ambos jóvenes se opone a su relación, por eso Sara y Lorenzo suelen encontrarse en una cueva, a orillas del mar, donde les sorprenderá la marea y morirán ahogados. Esta cueva la visitan hoy los enamorados, dice el anónimo autor de la leyenda en El Museo de las familias, y allí graban sus nombres (25-7-1850, pág.11). La historia se refiere bajo el pretexto de la correspondencia entre dos amigos y añade el grabado del encuentro de Sara y Lorenzo en la cueva. 


\section{El espacio imaginado de la Cueva de Hércules}

Un hito trascendental en la aventura caballeresca es el ingreso y conquista del palacio encantado, lugar donde ocurren fenómenos prodigiosos o mágicos que ponen a prueba las virtudes, valentía y deseo de gloria del héroe. Dicha aventura exige al protagonista coronar victoriosamente una serie de pruebas: el reconocimiento del lugar mágico, su acercamiento a él, el cruce de umbral - tras superar todas las dificultades que se lo impiden (signos, barreras, guardianes, vaticinios, monstruos, etc) en completa soledad (sin armas ni compañeros) - hasta llegar el centro o eje mágico de la cueva (lugar donde nadie ha estado antes) (Neri, 2007: pág. 46). Allí es donde el héroe recibe en muchas ocasiones una revelación profética ${ }^{8}$. Concluida la aventura y desentrañado el misterio desparece el hechizo de la arquitectura maravillosa, el edificio se desploma, es santificado por una rehabilitación sagrada (como en la «Historia de Alarabi») o comienza a recibir un uso común.

Estos son también los hitos narrativos del relato de la Cueva de Hércules y Palacio encantado de Toledo, leyenda geográfica e histórica de antigua tradición literaria, vinculada a la justificación del fin de una dinastía y la explicación de la invasión musulmana (Miralles, 2008:129). Sobre la vecindad de los relatos de la cueva encantada de Toledo con la imaginería de la fábula caballeresca volveremos luego. Nos detenemos ahora en la particularidad de que la leyenda haya sido edificada sobre un espacio en transformación que combina lo natural y lo artificial, una cueva cerrada e inscrita — según las versiones- en un palacio o en una torre, o comunicada con ellos por pasadizos subterráneos, y de otra parte, edificada sobre un «no lugar», un espacio nunca visto, el construido textualmente por las antiguas crónicas medievales 9 .

8. El ejemplo más característico de Cueva de los Encantos es, sin lugar a dudas, la Cueva de Montesinos. Sin embargo, quizá por la acuñación novelesca realizada en El Quijote, las referencias a esta cueva en la prensa romántica no tienen lugar en el contexto de la leyenda sino como lugar común mencionado en textos literarios o en artículos de opinión, para indicar algo oscuro o misterioso (como pueden ser las explicaciones políticas). Al respecto se lee en El Clamor público: «Cuando esperábamos que del periódico apostólico saliesen rayos de vivísima luz que nos iluminasen, solo hemos visto tinieblas en el fondo del artículo que ayer nos dedica. Tan a oscuras estamos después de haberle leído, como si nos hubiesen sepultado en las profundidades de la cueva de Montesinos» ( $\mathrm{n}^{\circ} 2778$, 17-8-1853, pág.1). A lo máximo que moverá tanto el «espíritu minero» de los tiempos como el avance del cervantismo será a la exploración de la cueva: «acompañados de un práctico encontramos en 1840 la boca de la ponderada Cueva de Montesinos que ya se nos anunciaba por el ruido prolongado y acuosos vapores que de su seno se desprenden» G. [arcia?] del C. [orral?] El Clamor público, nº 630, 9-6-1846, pág. 4.

9. Existe una importante bibliografía al respecto que evalúa la actividad de los cronistas. Los primeros en determinarla fueron M. Menéndez Pelayo (1897) y R. Menéndez Pidal 
Si aceptamos el testimonio de Lorenzo Franciosini en 1626 ya no se recordaba su ubicación ${ }^{10}$. Lo mismo indicaría Feijoo cien años más tarde, en su Theatro Crítico al asegurar que la especie de la cueva era una superstición abandonada por el vulgo ${ }^{11}$. Los datos históricos más antiguos recabados sobre la cueva procedían del reconocimiento realizado por el Cardenal Silíceo en $1546^{12}$ cuando, es de suponer, todavía era visible la puerta de la cueva en los bajos de lo que luego fue la iglesia de S. Ginés. Pero en 1826 ya no existían trazas de aquella puerta cerrada. Cuando Washington Irving visitó la iglesia en ese año, junto a un pequeño grupo de arqueólogos, pudo constatar que el sótano de S. Ginés había sido pavimentado de nuevo, con lo que era imposible localizar indicios de la cueva mágica; por ende, el guía local no parecía saber nada de la cueva, aunque sí recordaba haber oído decir que en la entrada de la iglesia había un arco de obra maestra que podría haber formado parte de una cueva subterránea ${ }^{13}$.

(1924). Los relatos del arzobispo Rodrigo Jiménez de Rada, el autor de la crónica General de Alfonso X, Díaz Gámez en su Vitorial, Alfonso Martínez de Toledo en la Atalaya de las crónicas, junto a varias relaciones árabes (en especial la Crónica del Moro Rasis) tejieron los hilos de la leyenda que otros autores más cercanos, Cristóbal de Lozano, Pedro de Rojas, el Dr. Salazar Mendoza, el Padre Mariana, o Julián del Castillo recogieron y repitieron, con diverso grado de credulidad. Consúltese también Ruiz de la Puerta, 1977.

10. Diálogos apacibles (he consultado la edición de 1684, Génova, Chöuet, 194, diálogo entre Poligloto y Filosceno). En cambio sí muestran los toledanos a Poligoto un artificio desarrollado en la ciudad para subir el agua.

11. «La especie de la Cueva de Toledo ya casi enteramente se ha desaparecido del vulgo; mas la de la Cueva de Salamanca echó ondas (sic) raíces en él» (Feijoo, 1798: pág. 185). Antonio Ponz en el Viaje de España: «acerca de la cueva de Hércules, y de aquella torre encantada, le dixe ingenuamente, que no creía nada, y que tenía por patraña quanto se decía de aquellas escrituras, que vió, y leyó el Rey D. Rodrigo: historia mas propia para entretener muchachos que para ser leída por hombres de juicio. (Ponz, 1787, pág.231)

12. La expedición ordenada por el Cardenal Silíceo en 1546 tuvo por objeto desvanecer los temores populares, pero no sólo no logró eliminar supersticiones sino casi contribuyó a crear otras nuevas. Los exploradores pasaron todo un día de verano en la cueva, anduvieron como media legua, vieron las estatuas de bronce sobre el ara, y una de ellas cayó con tanto ruido que los espantó. También vieron dentro una corriente de agua que no pudieron vadear y como efecto del frío y humedad de la jornada y del contacto con el vaho pútrido de la cueva - próxima a un cementerio- varios de los expedicionarios enfermaron y murieron. Otra historia es la del padre de familia que entró en la cueva para buscar en sus riquezas el último recurso para su pobreza, y murió al día siguiente de salir de allí, atormentado por visiones siniestras y voces terribles. El hombre llegó hasta la sala del supuesto tesoro y la vio sembrada de huesos y calaveras. También solía hacerse referencia al mozo que huyendo del castigo de su amo recorrió la cueva y salió a tres leguas de Toledo, cerca de Añover.

13. Estos recuerdos sirvieron a Irving como prólogo de la narración del episodio de Rodrigo en sus Leyendas de la Conquista de España, que resumen ítems clásicos como los 
El primer uso concedido a la cueva, según decía la tradición, había sido el de cátedra nigromántica. Para este fin había fundado la cueva Hércules quien impartió algún tiempo en ella sus clases de magia negra. Al concluir su estancia en la Península el héroe cerró la cueva-palacio y prohibió la entrada en ella bajo la amenaza de terribles castigos. La cueva sirvió después de templo pagano, en tiempo de los romanos pudo ser utilizada como cloaca o como mina subterránea por la que escapar de un eventual asedio de la ciudad; los cristianos la usaron como catacumba y necrópolis; y, posteriormente, llegó a alojar el cementerio de la iglesia de S. Ginés, «Se ve, pues, por todo lo dicho, que la cueva de Hércules se ha prestado a todas las tradiciones igualmente», decía José Amador de los Ríos en 1845 (pág.328). Cada uno de los pueblos que había dominado en la Península había contribuido «a llenar de misterios aquel antro, mágico según unos y despreciable y de ninguna importancia según otros» (ibid.) Además de la recomendación de la monarquía hispánica, añeja como ninguna otra, la leyenda había servido para rebajar la culpa de su decadencia, explicaba Amador de los Ríos, pues siempre es más grato a los pueblos «atribuir sus desastres a cosas sobrenaturales y maravillosas que el reconocer su corrupción y su degradación». Así fue cómo, para justificar la pérdida y la degeneración del trono de Toledo, la leyenda se hizo hueco en la Historia de España (Amador de los Ríos, 1845: 328) ${ }^{14}$.

Del atractivo novelesco y dramático de la leyenda no lograron sustraerse cronistas e historiadores y, como es natural, por su relación directa con el tema de Rodrigo la historia de la cueva encantada de Hércules fue utilizada en multitud de obras literarias ${ }^{15}$. Pero como sucedió con otras leyendas vinculadas a ciudades de larga tradición histórica (Granada, Sevilla, Córdoba,

avatares de la expedición del cardenal Silíceo y otras historias repetidas desde antiguo sobre los peligros de la cueva.

14. El eje temático de la leyenda lo constituye el tópico de «la casa cerrada» (Krappe, 1924) de procedencia china y venido a Europa a través de los árabes. La historia del último emperador chino de una dinastía que se atrevió a abrir la tumba de Confucio podría haberse asociado a la historia de Rodrigo, que según dicen antiguos cronistas, robó el tesoro de una basílica cristiana; dentro de un cofre el rey encontró un pergamino que dictaba la excomunión de quien profanase el sagrado (Krappe Haggerty, 1924: pág. 307)

15. Pero antes de Irving, «la cueva de Hércules» había sido motivo frecuente en la literatura europea gracias a escritores como el marqués de Marqués de Sade ('Rodrigue, ou La Tour Enchantée, conte allégorique' vol. III, en Les crimes de l'amour, 1788), Walter Scott (The Vision of Don Roderick, 1811) Walter Savage Landor (Count Julian, 1812) o Robert Southey, (Roderick, the Last of the Goths, 1814). En su hermosa novela Notre Dame de Paris (1831) Víctor Hugo pone en boca de Esmeralda el romance de la casa encantada de Toledo. No podemos ocuparnos aquí de la tradición literaria de esta leyenda, para la que sería necesario un estudio específico; en este trabajo nos centramos 
etc) el relato de la cueva de Hércules fue invocado en época romántica principalmente en textos propedéuticos (guías de viaje, notas, artículos, polémicas, crónicas) más que en textos de aprovechamiento literario. La leyenda daba pie a la polémica por el prestigio que sumaba o restaba a un importante destino turístico, la antigua y magnífica ciudad de Toledo. Por entonces la leyenda se juzgaba ya una superstición vencida ${ }^{16}$. La nota particular que estas recreaciones agregaron sobre la tradición fue el descrédito de Rodrigo, contra el propósito mismo de la leyenda. En efecto, al referirse al episodio los antiguos cronistas habían destacado que la caída de los reyes y las revoluciones de los imperios eran acontecimientos de tal magnitud que, necesariamente, tenían consecuencias no sólo en el mundo moral sino también en el físico; por ello podían ser anticipados por maravillas y prodigios como el de la destrucción del palacio y la formación consecutiva de la cueva. La responsabilidad moral del rey era atenuada por la acción aciaga del destino. Pero en las versiones que analizamos aquí no hay disculpa para Rodrigo, que pierde su reino tras haberse perdido a sí mismo. En las recreaciones románticas no hay necesidad para explicaciones penúltimas; la superstición, sugiere con ironía José Joaquín de Mora en su poema Don Opas (1840), brota libremente sobre el humus de la culpabilidad: «Cuando el rugir del infortunio suena / Superstición redobla su energía / «Nunca hay calamidad sin alma en pena, / Visión duende, fantasma o profecía (Canto VIII).

Prestando atención a estas versiones españolas de los años 30 a 50 destacaremos en primer lugar la novela de García Bahamonde, Los Árabes en España, ó Rodrigo, último rey de los Godos (1832), la crónica-leyenda de Basilio Sebastián Castellanos «La Torre encantada» (1837), algunos fragmentos incidentales en el poema bufonesco de José Joaquín de Mora, Don Opas (1840) así como el tardío romance histórico de García Tejero, «Pelayo. Año 718» (1858). En el mismo formato de Castellanos, y bajo el rótulo «El palacio encantado», Víctor Balaguer haría después una versión de la leyenda en un capítulo de Los frailes y sus conventos (1851: 317-321) justificando el excurso sobre la cueva

exclusivamente en la historia de la cueva maravillosa y sus vínculos con la tradición popular.

16. Fernando Mellado no tenía ninguna duda sobre la falsedad del mito. «Hoy los amores de Florinda, la cueva y el arca, todo está reputado por una fábula; es verdad que los que vivimos en este siglo tenemos la incomparable dicha de no creer en nada» (Mellado, 1849: pág.88). Es significativa al respecto la instrucción de los redactores del Museo de los Niños cuando refieren la historia «A nosotros nos parece este pasaje asunto de pura invención, y así lo aseguramos á los jóvenes que leen el Museo de los Niños, y en este supuesto deben caminar siempre que le vean consignado en nuestra Historia (vol. 2.1850, pág.331) 
de Hércules con la apelación al recuerdo de la leyenda de Rodrigo que, naturalmente, habría de surgir al visitante de la Cartuja de Jerez. Finalmente, la novela de Juan de Dios Mora, Florinda, o, La caba (1853) dedicó un capítulo a la aventura de la cueva a modo de paráfrasis narrativa de lo expuesto en el drama de Miguel Agustín Príncipe Don Julián (1839). También la leyenda recibió atención en un libro sorprendente, Animales célebres de todos los tiempos $y$ de todos los países (1858) de José Castro y Serrano a propósito de Orelia, el caballo de Rodrigo.

Pero quizá de todas estas recreaciones la más conseguida haya sido la narración de Washington Irving en los cp. VI y VII de las Legends of the Conquest of Spain $(1835)^{17}$. Para el relato de Washington Irving hemos seguido en estas páginas la traducción reproducida en La Crónica en 1845, por dos razones, en primer lugar la tardía circulación de traducciones directas del autor americano; secundariamente, por lo significativo del año en que el periódico publica esta traducción. El interés del periódico por la historia coincide con el desplazamiento de varios miembros de la Comisión Central de Monumentos Históricos para trabajar en el proyecto de catalogación y restauración de monumentos. José Amador de los Ríos, a la sazón secretario de esta Comisión, aprovecharía la experiencia para publicar unos meses más tarde su obra Toledo Pintoresco en la cual ocupa un apartado específico la tradición de la Cueva de Hércules. En este capítulo el erudito argumenta que el efecto principal de la leyenda fue conceder a la corte de Alfonso vi una antigüedad verdaderamente prodigiosa ya que los testimonios de los historiadores atribuían la construcción de la cueva a Túbal, hijo de Jafet y nieto de Noah. Es decir, los orígenes de Toledo se remontaban a los primeros días de la Humanidad. Cuando Amador de los Ríos publica su libro ya era una opinión ampliamente difundida que la cueva de Hércules no había sido más que una cloaca romana e incluso había quien dudaba que hubiera existido alguna vez. Como recordaría más tarde Sixto Parro en su libro Toledo a la mano (1857), Francisco Santiago Palomares, buen conocedor de la legislación y costumbres romanas, y compañero de Antonio Ponz en su viaje de reconocimiento a Toledo en 1753, había sentenciado que la cueva de Hércules no podía haber sido más que una cloaca para el desagüe de las inmundicias de la

17. Los dos capítulos son traducidos por La Crónica (marzo y abril de 1845: bajo el rótulo «El rey Rodrigo recibe una embajada extraordinaria», «Historia de la torre encantada y maravillosa» y en La Esperanza. ( ${ }^{\circ} 1346,15$ de febrero pág 4 . y n ${ }^{\circ} 1349,19$ de febrero de 1849, pág.4). En 1862 reitera la traducción un periódico barcelonés, La Luz. 
ciudad $^{18}$. Como tal fue catalogada en el Diccionario geográfico de Pascual Madoz (Madoz, 1840, pág. 832). El académico correspondiente Nicolás Magán hará un resumen de todas las noticias, fabulosas o no que circulaban en torno a la famosa cueva en un artículo para el Semanario Pintoresco Español, «La cueva de Hércules» (1840). En su opinión era indubitable que la cueva había existido. Un año antes un grupo de jóvenes universitarios había intentado el reconocimiento de la cueva con el propósito de confirmar las dos hipótesis y había llegado a localizar el primer gran arco subterráneo (Martín Gamero, 1862, I, lb.II, pág. 192); sin embargo, una vez dentro de la bóveda, tanto la imposibilidad de continuar el acceso como la evolución de los acontecimientos políticos, entre ellos el golpe de Espartero, frustraron el proyecto.

A finales de 1850 y principios del 51 volvió a impulsarse la excavación en los sótanos de S. Ginés. Para los gastos de ejecución del proyecto se había abierto suscripción pública que contaba con el apoyo del jefe político interino y aspiraba a la protección del gobernador propietario, a su vez, presidente de la Comisión de Monumentos Históricos y Artísticos (La Esperanza, 23-41851, pág. 3) ${ }^{19}$.

Ángel Magán, oficial segundo del gobierno de Toledo resumía en un artículo publicado en abril de 1851 en El Heraldo de Madrid lo descubierto hasta el momento: una serie de arcos de piedra sillería de gran dimensión, prueba de la existencia de varias cuevas enlazadas entre sí de época romana y árabe. Los descubrimientos desautorizaban la opinión antigua de que la cueva hubiese servido como cloaca de la ciudad. Pero Magán se permitía también una alusión velada a la Toledo Pintoresca de Amador de los Ríos: «De este número es un ilustrado autor contemporáneo, quien con alguna ligereza, salva sea su reputación literaria, en cierta obra popular asegura que la cueva llamada de Hércules no pasa de ser una cloaca» (Magán, 1851: pág. 3) El Sr. Magán se dolía de ver tratado de un modo «ignominioso» lo que consideraba un

18. «Algún autor del siglo pasado (...), aventuró la racional y muy aceptable conjetura de que la pretendida cueva de Hércules debía ser ni más ni menos que una cloaca» (Sixto Parro, 1857: págs.647-648).

19. En 1873 el solar de S. Ginés era propiedad de D. José de los Infantes y se dudaba de que la cueva hubiera existido. Para probarlo las excavaciones tendrían que haber continuado por los sótanos de las casas vecinas, y la sociedad arqueológica no pudo reunir el dinero para la indemnización de los propietarios, razón por la que todo quedó en suspenso. La expedición de 1838 fracasó porque hubiera necesitado del permiso de traslado de los enterramientos de la bóveda; por eso los trabajos no pasaron de la puerta de S. Ginés. Lo cierto es que las casas que rodeaban a S. Ginés eran muy antiguas y no del todo imposible que en sus cimientos se escondiese el secreto de la cueva, restos de un templo de Júpiter en todo caso. Apud, Mariano de la Torre Roldán, «Cueva de Hércules en Toledo», La Ilustración Española y Americana, año 17, n² 2, 8-1-1873, págs.31-32. 
valioso monumento toledano, sobre el que tanto se había escrito. Tal vez no hubiese estado allí el palacio de Rodrigo pero, sin duda, aquella cueva había podido ser «refugio o tumba soberbia de cristianos, morada real de los árabes o mezquita suntuosa» (ibid) y lo más grave del asunto es que estas opiniones repercutían en la valoración que los turistas podían hacer del patrimonio de la ciudad, estando próxima «la ocasión en que lo puedan examinar con detención y estudio los muchos viajeros que suelen visitarnos en la Semana Santa para admirar los monumentos de Toledo» (ibid) ${ }^{20}$.

En este clima, dice el historiador de Toledo Antonio Martín Gamero, «cayó como una bomba sobre ellos el artículo de un literato muy conocido y respetado en la ciudad, quien desde la corte, enterado de los resultados de las exploraciones hechas escribía» (...). Se refería Martín Gamero, naturalmente, al nuevo artículo de Amador de los Ríos publicado en noviembre de 1851 en el Semanario Pintoresco Español que rectificaba lo suscrito por él en su Toledo pintoresco: «La denominada Cueva de Hércules, ni es tal cueva maravillosa ni es cloaca» (Amador de los Ríos, 1851: pág.383) La cueva era romana, sí, no del tiempo de Hércules; pero tampoco cloaca a juzgar por la estructura de su planta. Las enormes bóvedas encontradas, sostenidas sobre pilares, eran indicio de que la cueva había servido de cimiento de un importante edificio: «Semejante fábrica está manifestando que fue destinada a recibir un edificio tan fuerte y robusto como ella; y por la situación, por la importancia de lo existente y por la ostensión del lugar que ocupa, no admite duda en que fue aquel un templo gentílico» (ibid.)

Pero, añadía el erudito, las excavaciones habían logrado hacer morir de una vez una ilusión. «La tradición que ponía la Cueva de Hércules bajo la demolida iglesia de San Ginés, ha muerto: para alimentarla por algún tiempo hay necesidad de buscar una nueva cueva. ¿Sera posible hallarla? (...) (págs. 382-383).

El palacio de Hércules había sido desencantado definitivamente. Y concluía Amador de los Ríos: como van los niños «tras la luna de cerro en cerro»

20. A esta pulla siguió un artículo de Amador de los Ríos que no he podido localizar quizá porque la contrarréplica de Magán se publicó mucho tiempo después por falta de espacio en el periódico. «En el Heraldo del 24 del actual se ha publicado un artículo en el que se permite a D. José Amador de los Ríos una contestación bastante fuerte al que se insertó en el del 13 sobre la llamada Cueva de Hércules de Toledo. Habla ex cathedra y en un tono que yo no le seguiré porque no es mío; pero sin ese acumulo de citas de que hace alarde, y se ha afanado en rebuscar para salir a la arena, debo decirle que antes de leer su artículo sabía y sé que en lo antiguo se edificaron cloacas, algunas de ellas magnificas; que ignoraba, e ignoro que en Toledo se hayan construido» (1851a: pág.3) 
así podrían continuar los exploradores de cueva en cueva hasta alcanzar «el último desengaño» (Amador de los Ríos, 1851: pág. 383).

\section{Marcos espaciales y genéricos en «La cueva de Hércules»}

Como antes se ha dicho, la leyenda de la Cueva de Hércules dibuja un espacio ignoto caracterizado a través de los spacial frames (Ryan, 2009), los imaginarios culturales propios de la versión del relato en cada momento y el mundo narrativo que comparten productores y receptores de la leyenda. Al comienzo de su circulación, con las antiguas crónicas del moro Rasis, Lucas de Tuy o el arzobispo Rodrigo de Toledo, el texto toma prestados diversos elementos del marco espacial dibujado por la cuentística oriental y la novela de caballería. Esto explica el cúmulo de tópicos de la literatura caballeresca que van heredando las sucesivas versiones de la leyenda, aún patentes, por ejemplo, en el relato de Basilio Sebastián Castellanos en 1837 (traducción de la Revue Hiberique sic) donde la leyenda confluye con la historia pseudo-caballaresca de la Torre del Placer y de la Pena ${ }^{21}$. Pero la evolución de los spacial frames llevará la reescritura de la leyenda hacia otras tonalidades, como la gótica y vampírica en el drama de Miguel Agustín Príncipe, Don Julián (1836). En cualquier caso, cada versión de la leyenda es construida a través de los itinerarios de los personajes, del palacio de Rodrigo al palacio de Hércules, insertos

21. Paseando por Toledo y tras haber visitado la catedral gótica, la mezquita, y el alcázar de los Alfonsos, el narrador sale al campo, «reflexionando sobre los notables sucesos de aquella célebre ciudad» en las diversas edades y sobre el carácter efímero de las obras humanas. En el promontorio que domina la ciudad encontrará al anciano que le refiere la tradición de la Torre del Placer y de la Pena, que aloja la cueva encantada. La referencia alude de inmediato arquitecturas maravillosas de la novela de caballerías como la altísima y fúlgida Torre Desamorada, donde vive cautiva la princesa Lindabrides (Espejo de Príncipes y caballeros o El Caballero del Febo de Diego Ortúnez de Calahorra, 1555; Neri, 2007, págs. 38-41), custodiada por dos estatuas que portan hachas de acero. Encima de la puerta un letrero de oro previene la entrada en la torre. Otro ejemplo del estilo puede tomarse del Clarian de Landanís. El temor que inspira la entrada tenebrosa de la Gruta de Ércoles, un lugar «donde ningún hombre terrenal había entrado que saliesse» (Clarián de Landanís, I, libro I, apud. Neri, 2007: pág. 122) es soporte para una de las aventuras. Dentro de la cueva el caballero encuentra todo tipo de maravillas, una mesa de oro, columnas, la estatua majestuosa de Ércoles, con la que razona, el auxilio de los letreros e inscripciones, etc. El héroe regresará victorioso y dueño de la valiosa Espada de la Esmeralda o de Hércules. La cueva es obra de maravilla y riqueza y se sitúa al pie de la montaña. Sus puertas incandescentes no se pueden franquear más que en días determinados de la semana. Los que tratan de entrar son encontrados en el lago cercano, amortecidos. De la cueva sale a veces una serpiente voladora. El hechizo de la Gruta de Ércoles tiene su origen en una circunstancia familiar a los textos examinados hasta ahora, los amores incestuosos de un mal rey Quipolo por su hermana, a la que gozó dentro de la cueva.

Anales, 25, 2013, pp. 397-427 
en una cronografía determinada, el tiempo mítico de la fundación de Toledo, el presente de la monarquía corrupta, y el porvenir vaticinado en el cofre custodiado en la torre.

El argumento es conocido y puede secuenciarse narrativamente del modo siguiente:

-Rodrigo rompe la tradición de sus antepasados. Al subir al trono Rodrigo rompe con la tradición antigua de añadir un candado a la puerta del palacio de Hércules, la cual le transmiten, dice Irving, los dos ancianos que custodian la torre maravillosa. Estos dos guardianes son los herederos de aquella docena de hombres que, según explicaba la Crónica del Moro Rasis (Menéndez Pidal, 1924: pág. 19), habían sido escogidos por Hércules para guardar su candado con la orden de ser siempre sustituidos. Basilio Castellanos mantendrá en «La torre encantada» la custodia de la pareja de ancianos (1837: pág.134) mientras que José Joaquín de Mora, en Don Opas, más en la línea romántica, hará llegar el vaticinio a Rodrigo a través de un ermitaño (1840: LIX). En el mismo sentido, en el Pelayo de García Tejero la predicción la hace una maga, vestida de blanco, que muestra a Rodrigo una estrella roja en el firmamento, signo de la catástrofe que se avecina y pronóstico no sólo de la caída del rey sino de todo su pueblo: «no caerás solo, tu raza / cumple el término, los Godos / víctimas sucumben todos / de aleve impura traición» (1858: pág.16) Con el correr del tiempo y la tendencia de los productos populares al incremento los candados se multiplican y exigen a los criados de Rodrigo enorme aplicación para ser abiertos (Irving) y hasta pueden ser desplazados de la cueva a una sala de palacio, la «de los candados» (Mora, 1856: 66). Inscripciones, monstruos, animales fieros, ancianos y, por supuesto, el autómata gigantesco cumplen la misma función en el relato: custodiar el secreto tras el umbral infranqueable. Desde el comienzo la fábula se organiza en torno a la polaridad dentro-fuera, permitido-prohibido, oculto-descubierto, realidad-ilusión.

-Rodrigo decide entrar en la cueva peligrosa. La curiosidad de conocer lo secreto, la ambición de convertirse en el destinatario de una predicción ambigua y la codicia de los tesoros ocultos deciden al rey a violentar la torre. Los textos tardo-románticos inciden en esta caracterización prometeica. Era fama - declara García Bahamonde- que quien abriese «el antiquísimo alcázar respetado por el tiempo» traería la ruina al país en castigo de su curiosidad (1832: pág.41). La motivación de Rodrigo en las primeras versiones de la leyenda (la carestía tras el despilfarro o la imprevisión) se matiza en los textos aludidos para adecuarse al prototipo byrónico (la curiosidad y la lascivia). Para Castro 
y Serrano son la frivolidad y disipación de Rodrigo las que le hacen olvidar la ceremonia del candado; cuando el peligro de la invasión sea inminente el rey franqueará el palacio con el mismo atolondramiento para conocer qué le reserva el destino (1858: pág. 254). La finalidad de este hito narrativo es mostrar no sólo el valor del rey sino también su carácter soberbio y extremado puesto que Rodrigo entra en el palacio no sólo movido por la codicia sino también por la curiosidad, ya que su destino está escrito en el pergamino del arca. «Cuando se supo aquel extraño arrojo / causó en Toledo escándalo infinito / —aclara Mora en Don Opas — «En uno admiración, en otro enojo / Uno lo llama hazaña, otro delito» (LXIII). Porque el destino de Rodrigo es el de todo el pueblo sus cortesanos se sienten con derecho a impedirle la transgresión $^{22}$. Rodrigo desoye todas las recomendaciones de su consejeros. En la versión de Irving, el arzobispo de Toledo trata de contener la temeraria curiosidad del rey con el recuerdo de las amenazas. Víctor Balaguer hará la escena aún más dramática: «uno de sus privados se arrojó a sus pies conjurándole en nombre de todo lo que amaba para que se volviese atrás de su propósito y no quisiese arrostrar la ira el cielo» (1851: pág. 320).

Según la tradición general, que es la que sigue Irving, el rey entra en la cueva acompañado por sus caballeros al menos hasta la primera aventura de la estatua animada. Sin embargo, corresponde mejor a la prueba iniciática del paso del umbral que la experiencia se realice en solitario. Así ocurre en la fabulación de Víctor Balaguer. Sordo a las suplicas de sus consejeros, Rodrigo se niega a ser acompañado en su tentativa «por temor de faltar a lo que mandaba la común tradición» según la cual «era preciso que el rey bajase de noche a la cueva, solo, sin armas, y vestido con su traje más ordinario. De otra manera no se cumplía con el destino» (1851: pág. 319). Sin hacer caso de los ruegos de sus vasallos se dirige «solo y tranquilo» «hacia el terrible castillo de los encantos» detalla Castro y Serrano. Y como indicio del carácter mágico del castillo a su alrededor el campo aparece mustio y sin flores. (1858: pág. 254)

-El edificio encantado opone resistencia. La torre se emplaza fuera de la ciudad. Por la tendencia al incremento a que nos referíamos antes, en el relato de Víctor Balaguer la cueva se extiende ya seis leguas desde lo alto de la ciudad

22. La ironía de J.J. de Mora es patente en García Bahamonde que habla de Rodrigo en estos términos: «Rodrigo, el príncipe deseado de su pueblo, el amable, prudente y justo, se convirtió en opresor, cobarde y cruel. Si derogó algunas de las escandalosas leyes de su antecesor, fue más por una política estudiada que por bondad de corazón, y por ganar las voluntades de los partidarios (1832: pág. 12). «Para mayor seguridad se propuso Rodrigo llamar cerca de sí a los emigrados del anterior gobierno, entre los cuales se hallaba Pelayo» (1832:pág.13) 
(1851: pág.318). Su profundidad se ha multiplicado por cinco desde las primeras descripciones de los cronistas. Irving pinta una torre exenta, fúlgida, cilíndrica, construida sobre una alta roca inexpugnable y sostenida en sus cimientos por «cuatro leones de bronce de la altura de un hombre a caballo» (1845: pág. 220) «Los muros estaban formados de pequeños pedazos de jaspe y mármol, de diferentes colores, cuyo tamaño no excedía el de la mano de un hombre. Sin embargo estaban unidos de tal manera, que a no ser por la diversidad de los colores, se hubiera creído que era una sola y misma piedra» (ibid) Es decir, se trata de una arquitectura maravillosa, imposible, de origen mágico, progresivamente más inverosímil.

Basilio Castellanos explica que la torre es redonda, encaramada sobre un pedestal con cuatro leones de bronce, tal alta «que ninguno es capaz de verla» (1837: pág.134) hecha de pedazos de jaspe y mármol y que en sus muros se pronostica la Historia de Toledo. La brillante descripción de la torre brota en el relato de Castellanos de las imágenes evocadas por la contemplación de las ruinas de un supuesto palacio, y desde la narración de un lugareño. De la ensoñación toma también motivo García Tejero para referir la leyenda de la cueva «de la cual restos existen / sombríos muros, históricos» (1856: pág. 17). El palacio es un edificio exento que se puede escalar, describe García Bahamonde (1832:pág.44) Balaguer indica mecánicamente que la cueva todavía puede visitarse, cosa que como se ha dicho es incierta: «En tiempo de los godos había en Toledo una cueva, cuya tapiada boca se enseña aún hoy día, de la que se contaban maravillas» (1851: pág. 317). En todos estos casos se habla de un edificio visible y exento, ruinoso o maravilloso.

Pero los narradores de la leyenda también pueden referirse a un palacio subterráneo sumido dentro de la cueva, como en el drama de Miguel Agustín Príncipe, en que Rodrigo y Don Julián llegan al palacio por un pasadizo que comunica con el alcázar real (Príncipe, 1836: pág. 85). En la novela de Juan de Dios Mora, la cueva es reducida a lo que llaman «la sala de los candados» mansión «de los terribles espíritus infernales» (Mora, 1856: 66) La descripción más elocuente al respecto es la de Balaguer: «contábase que en su interior existía un palacio encantado de magnífica, notable y primorosa fábrica, con muchos arcos, pilares y columnas todo de plata y oro; que en el fondo de este palacio había arcas de hierro con grandes tesoros» (Balaguer, 1851: pág. 318) García Bahamonde, sin embargo, describe la aventura con realismo: el pavimento y las paredes de la cueva aparecen humedecidas y malolientes, los reptiles corren por el suelo. La mansión la forman pilares de piedra y unos amplios arcos entre los cuales se ve una urna de madera. Al abrirla saltan las 
tablas podridas. En el fondo de la cueva suben unas escaleras (García, 1832: págs. 46-50).

El rey ordena abrir los candados de la puerta de hierro (orlada o no de inscripciones según las variantes de la leyenda) o, más prácticamente, manda echar abajo la puerta (José Joaquín de Mora, Víctor Balaguer). La opción de mostrar a los cortesanos abriendo uno a uno los candados, como hacía Irving, era sin embargo muy significativa, ya que hablaba de la resistencia del edificio encantado a la intrusión del héroe, y subrayaba el tono caballeresco del relato. Después de muchas horas luchando con los cerrojos toda la fuerza de los criados no bastará para empujar la puerta. En cambio, un leve toque de Rodrigo es suficiente, puesto que a él sólo está reservada la aventura. Las puertas se abren por si solas, en el relato de Castro Serrano, después de un segundo golpe de Rodrigo con la lanza, cuando el rey no se ha dejado intimidar por el rumor indefinible que llega de la torre, como de una gran batalla (Castro y Serrano, 1858: pág. 254). El rey ve delante de sí una gran estancia y un corredor que termina en una escalera (como también en las versiones de García, Castellano, Príncipe y Mora) Para García Bahamonde al abrirse las puertas sale de la cueva una columna de aire tan violento que apaga la luz de los expedicionarios (García, 1832: pág. 47).

En las tradiciones de la novela caballeresca la visita importuna de la cueva era defendida por letreros en el frontis de la puerta de ingreso, o por medio de criaturas monstruosas que impedían el paso (serpientes, perros, tigres, leones, estatuas animadas). En la leyenda de la cueva de Hércules existen los mismos signos intimidatorios. Algunas versiones hablan del frontis de la puerta, que advierte gravemente a los osados, aunque en términos quizá ambiguos ya que al infractor se le prometen los mayores males o los máximos bienes, es decir, la inscripción funciona como una especie de anzuelo para el héroe deseoso de fama y riquezas. Recuerda Víctor Balaguer: «Un letrero a la puerta de la cueva en letras griegas y en cifra decía: EL REY QUE ABRIERE ESTA CUEVA, Y PUDIERE DESCUBRIR LAS MARAVILLAS QUE TIENE DENTRO, DESCUBRIRÁ BIENES Y MALES» (Balaguer, 1851: pág. 319) ${ }^{23}$.

Otros signos intimidatorios derivan de la descripción de la cueva cuya extensión y profundidad no puede medirse, su acceso es difícil, y sus moradores se presumen terribles. El edificio encantado opone resistencia a los intrusos también por la fama de sucesos luctuosos. Washington Irving recordaba las

23. Belianís sólo podrá descifrar el letrero en caracteres arábigos que hay a la entrada de la Cueva de la Aurora, y que contiene un vaticinio, después de vencer al gigante que custodia la cueva (Belianís de Grecia, Burgos, 1547, apud, Neri: 2007, pág.102) 
hablillas sobre el perro terrible que tenía todas las llaves de la cueva y velaba noche y día el tesoro escondido por los romanos: «aún no se ha tenido noticia de ningún amante al oro que haya tenido valor para arriesgar una lucha con este terrible Cerbero» (Irving, 1845: pág. 194). La tradición fantástica del perro es sustituida en la novela de García Bahamonde por la presencia de fantasmas, bultos blancos gigantescos, y el resonar, cada noche, de lamentos humanos en su interior. De la cueva llegan también alaridos y ruido de combate. «Estas palabras, inventadas por el miedo, las / repetían a Rodrigo sus validos». Pero el rey, que quiere recuperar el prestigio ante sus vasallos, decide entrar de madrugada en el palacio "para probar su valor», explica García Bahamonde (1832: págs. 44-45). Para Miguel Agustín Príncipe el palacio es un antro de brujas donde se celebran aquelarres sabatinos y se sacrifica a los incautos que se atreven a entrar. Prueba de ello son los cadáveres que se encuentran después en el río, chupada la sangre y sin cabello. Del palacio salen todos males, de modo que «mientras permanezca en pie / Aqueste maldito alcázar / no hay que esperar el remedio / de pestes ni de tronadas» (Príncipe, 1839: pág. 40). Por su parte, José Joaquín de Mora recuerda burlón el riesgo de la aventura pues, según dicen las lenguas, no se ha oído de nadie que entrando en la cueva volviese a salir: «uno que quiso entrar se quedó mudo / él entrará, pero salir, lo dudo» (Mora, 1840: LXIII, pág. 444) ${ }^{24}$. Incluso se sospecha que el edificio es habitado por un monstruo, sugiere Víctor Balaguer: «las hablillas del vulgo estaban más en su sazón, merced a unos ruidos subterráneos que decían haberse oído, y a una visión horrorosa que despidiendo fuego por los ojos, la boca y las narices, se había presentado en la puerta a un pastor que por junto a la torre pasaba a deshora de la noche» (Balaguer, 1851: págs. 318319). O también, agrandaría Juan de Dios Mora «...en aquel palacio habitaba un formidable gigante o encantador llamado Harpalus, cuya boca era como

24. De estas tradiciones se hace eco Irving en otro lugar para hablar de la cueva de Boadbil. Cuantos han entrado en la caverna «no han vuelto a ver la luz», su profundidad es incalculable, si se arroja una piedra «atraviesa durante algunos segundos un vacío inmenso, hasta que, encontrando la punta de una roca, choca en ella con un estrépito semejante al de cien rayos encontrados, que al cabo de un nuevo intervalo muy abajo, muy abajo se precipita, silbando en un lago, y todo queda en silencio; mas este silencio no es muy duradero. El abismo parece conmoverse. Repentinamente un débil murmullo, un sordo zumbido se eleva de la inmensa profundidad. El estrépito se aumenta, crece y se aproxima, semejante a un tumulto confuso de una multitud agitada con un terrible choque de armaduras y ruido de timbales, como si algún ejército sorprendido se formase rápidamente en batalla en las entrañas de la tierra» (Cuento de la Alhambra, prólogo a las leyendas de Irving (Semanario Pintoresco Español, n ${ }^{\circ}$ 2, 18-10-1840, pág. 333).

Anales, 25, 2013, pp. 397-427 
un horno encendido, respiraba fuego y cuya cabellera, como la de Medusa, estaba erizada de silbadoras serpientes» (1853: pág. 86). En la novela de este autor los sábados se oyen en la cueva chirridos de cuervos y lechuzas, relinchos de caballos, silbos de reptiles. Las brujas y trasgos, presididas por un gigante montado en un monstruo volador, asoman por las ventanas y se divierten raptando a los muchachos del pueblo a los que chupan la sangre, rapan el pelo y arrojan al río.

Pero además, a la entrada de la cueva hay una gigantesca estatua de bronce o de hierro, que, sobre una mesa, o sobre un pilar muy alto, previene el ingreso dando golpes con una maza. Víctor Balaguer la hace golpear no en el suelo, sino en el «arca de hierro que se veía a sus plantas, produciendo un ruido tan fragoroso que hacía temblar de una manera siniestra las bóvedas como si fueran a desmoronarse sobre la cabeza del que imprudente allí guiara sus pasos» (Balaguer; 1851: pág. 321). Por la misma tendencia a la incredulidad Miguel Agustín Príncipe confiesa que los fantasmas que golpean el suelo no son más que conspiradores disfrazados (cuadro V, pág. 101).

Al verla, los cortesanos abandonan a Rodrigo. También según las versiones la estatua lleva en el pecho una inscripción que dice «hago mi deber» y en otras, letreros a derecha a izquierda, e incluso en su espalda.

Basilio Castellanos muestra una primera sala donde yace en una cama la estatua gigantesca de un guerrero que tiene en la mano un pergamino en el que declara ser Hércules: «Temerario que diriges aquí tus pasos, mira el mal de que serás causa... ¡Por mí la España fue conquistada y poblada...! ¡Por ti será destruida y perdida. A esta provocación responde Rodrigo: «ninguno puede conocer el porvenir sino el verdadero Dios» (Castellanos, 1837: pág. 135); esto es, el rey conjura la estatua como si estuviese exorcizando un demonio y el autómata se detiene ${ }^{25}$.

-El rey llega al centro del edificio mágico. En la mayoría de las versiones románticas, después de salvar el obstáculo del autómata, el rey llega a la cámara del tesoro, un aposento de paredes brillantes y transparentes como de cristal

25. En la versión de Irving, Rodrigo se dirige a la estatua solemnemente: «quien quiera seas, sabe que no vengo a violar este santuario, sino a penetrarme de los misterios que contiene; por tanto le mando que me dejes pasar con seguridad. (Irving, 1845: pág.194) Así lo refiere Balaguer: «—O tú quien quiera que seas el solitario huésped de esta caverna, yo soy el rey Rodrigo que aquí he llegado fiado en mi valor y en el destino que promete maravillas al monarca que penetre en esta cueva. Si el poder mágico..., dices te lo permite, dime tú, el caballero de la maza, lo que me toca hacer para apurar el destino y el misterio; pronto estoy á todo, que ante nada retrocedo» (Balaguer, 1851: pág. 321). 
(Irving) y de cuatro colores, rojo, verde, negro y blanco (Castellanos), iluminado por una luz inexplicable aunque se encuentra bajo tierra.

El centro de la sala lo ocupa una mesa de alabastro, dice Irving (la mesa de Salomón, según tradiciones antiguas cubierta de relieves e inscripciones y fabricada en oro y piedras preciosas). En la mesa hay un casco de oro, que Rodrigo se pone de inmediato, y una caja de oro, ricamente engastada en piedras preciosas, asegurada con una cerradura de perlas. Los caracteres griegos que rodean la mesa declaran que Hércules fue el fundador de aquella torre en el año tres mil y seis. Una inscripción en el cofre dice: «En este cofre se encierra el misterio de la torre. Ninguna otra mano, sino la de un rey, puede abrirlo; pero guárdese de hacerlo porque le serán revelados acontecimientos maravillosos que deberán realizarse antes de su muerte «(Irving, 1845: pág.221). Para Castellanos, el cofre se ubica dentro de una columna que puede abrirse mediante una puertecilla coronada por una inscripción griega, la cual atribuye la construcción de la cueva en 3006 a Hércules. El cofre es de plata sobredorada cuajado de piedras preciosas, y cerrado con un magnífico broche.

«¿Qué debo temer del conocimiento del porvenir?»—se pregunta el rey al abrir el arca y encontrar en ella tan sólo un lienzo en el que se ven figuras de guerreros a pie y a caballo, vestidos extrañamente. Una inscripción en el lienzo dice: «monarca temerario, considera a los hombres que han de arrojarte de tu trono y subyugar tu reino» (Irving, 1845: pág. 51). García Bahamonde precisa en su novela que en la escena del lienzo los guerreros miran con ojos feroces a una noble matrona, que representa la monarquía goda, pisotean las armas de los godos y empuñan el cetro de la corona (García, 1832: pág. 51). La repulsa al rey absoluto es expresiva en la obra de Miguel Agustín Príncipe al exculpar completamente a Don Julián «¿Qué importa / si el que llamas traidor liberta a un pueblo / De sus triste cadenas? No se vende / La Patria que no existe. El moro fiero / Viene a darnos la Patria» (cuadro V, pág. 101). En el arcón secreto hay tres lienzos y una moneda. La moneda lleva su efigie, y de ella dice irónicamente el rey «ies posible que en mi imperio / para eterno vituperio / un grabador no se halle? / siempre me retratan mal» (Príncipe, 1836: pág.7 ${ }^{26}$. En uno de los lienzos hay un «figurón estrambótico y de

26. Sobre los pasos de M. A. Príncipe, Juan de Dios Mora hace que el rey encuentre en el cofre una moneda de cada uno de los reyes godos, incluida una suya, y un pergamino en que aparecen los doce hombres que reciben el mandato de Hércules, además de los retratos de Florinda y Pelayo. También el héroe de caballerías topa en el centro del edificio encantado, como en la Cueva del Hada Arquía, de Felix Magno (III, Barcelona 1531) su propio retrato (Neri, 2007: pág. 56). 
estatura colosal»(remedo del autómata gigante). En el lienzo está escrito el futuro que aguarda a Rodrigo, de ahí que en las diferentes versiones aparezca un signo por el que rey puede reconocer su propia historia. En otro lienzo lo que se ve es el retrato de Florinda, y en otro más las figuras de los árabes, y la inscripción que lleva el propio dosel del lecho del rey, «Toletus pius» y también «Per hos Hispania peritura» (cuadro V, pág. 101). En el lienzo donde se ven los guerreros puede leerse en letras de sangre, dice Balaguer: «Quien aquí llegase y esta arca abriere, perderá España, será vencido de estas gentes» (1851: pág. 222).

Irving permite que el lienzo se anime y el rey pueda verse a sí mismo de espaldas, en mitad de la batalla, huyendo de los enemigos, con la armadura y divisa que le pertenecen, montando «un caballo blanco, muy semejante a su caballo de batalla, Orelia». (Irving: 1845: pág. 222)27. El personaje vive un momento de alucinación. Se oye el tremolar de las cornetas, los relinchos de los caballos, el choque de los caballos. El lienzo se ensancha y se dilata transformándose en una especie de bandera que cubre el muro, atraviesa el techo y se pierde en el aire, pero «si todo de aquel cuadro era una pintura animada o una visión, o una legión de espíritus endiablados conjurados por algún poder sobrenatural, ninguno de los circunstantes pudo definirlo» (Irving, ibid.)

José Joaquín de Mora hace la parodia de esta escena al explicar en un tono bufo cómo al abrir la caja el rey sale de allí un fuego sulfúreo que llena de luz la cámara y hace escapar «Cual profunda ratonera, espíritus impuros a millones» (Mora, 1840: LXXIII, pág. 417). La alucinación de Rodrigo ocupa varias estrofas: «Lo que pasó en la torre es un problema / que nuestros ilustrados escritores / Refieren, cada cual, según su tema: / Pero que allí se vieron mil horrores / Para ninguno es ya duda o dilema / Y en cuanto a que lucieron sus primores / Con el pobre Rodrigo los demonios / Unánimes están los testimonios (LXV). Rodrigo se sumerge en niebla oscura por un pasadizo estrecho, tentando la pared hasta que se transforma en sala. Grita y el eco le responde, le faltan las fuerzas y, como no puede orientarse, se echa al suelo.

27. El episodio de Orelia es el que da lugar a la narración de Castro y Serrano. Al salir Rodrigo del castillo, trémulo y desencajado, crujen los cimientos del edificio, salen ríos de fuego por las puertas y ventanas, y el rey, que intenta ponerse a salvo, no puede moverse porque sus pies parecen «atados por el miedo». En este punto aparece un caballo que acude en su socorro y el rey salta encima y huye hacia Toledo. Pero escucha una voz que dice «Con él te salvas y con él te perderás» (Castro y Serrano, 1858: pág. 255), si bien el rey la atribuye a un engaño de sus sentidos aterrorizados. Al llegar a la ciudad Rodrigo busca al dueño del caballo para comprárselo, pero no lo consigue. Desde entonces Orelia se convierte en su caballo. 
Descubre entonces la superficie bruñida de la caja. Cuando la abre se produce una explosión y sale de allí todo un festival de demonios que desfila ante Rodrigo «grandes, chicos, medios, flacos, gordos / lívidos, pardos, negros, bayos, tordos» (LXIII). De una especie de nicho será liberado un demonio gigantesco el cual manifiesta lo siguiente: «en prueba del agrado / con que hemos aceptado tus servicios / Dejamos en tu trono vinculado / Uno de nuestros mayores beneficios / En nuestro idioma. Allí queda estancado / Bajo nuestros diabólicos auspicios / un vástago fecundo del infierno / ese don que se llama desgobierno» (LXXXIII)

-El edificio es desencantado. El rey Rodrigo pierde el sentido y se encuentra sin saber cómo a la puerta del palacio. «Respecto a lo que en ella vio andan discordes las historias» agrega Castro y Serrano, poniendo en duda si todo ocurrió realmente o tan solo fue un sueño (1858: pág. 254) Balaguer prosigue el relato en el tono folletinesco y descreído que le caracteriza. Explica el autor que Rodrigo sintió la nube de un vértigo pasar por su mente: "parecióle como que retorcían su cerebro con unas tenazas ardientes, volvió a todas partes unos ojos vidriosos, creyó ver danzar mil fantásticas visiones en torno suyo mezcladas con las cabezas de los monstruos y reptiles de la cornisa, dio vacilante algunos pasos, batió el aire con las manos como el hombre que se ahoga, y cayó desplomado en el suelo sin voz y sin movimiento (Balaguer, 1851: pág. 323).

Rodrigo regresa a Toledo. En casi todas las narraciones románticas, a excepción de Castellanos, se omite el episodio inverosímil introducido en la crónica del Moro Rasis donde se cuenta que un águila que llevaba en el pico una tea encendida, prendió fuego al edificio encantado, que se desplomó. Las cenizas de la torre se esparcieron por toda España y aquellos sobre los que cayó la ceniza murieron en la batalla (Irving, 1845: pág. 222). Al menos, no faltan indicios de tal desenlace al decir que Toledo permaneció toda la noche alumbrada «por el rojizo resplandor de un incendio. Al día siguiente el castillo había desaparecido» (Castro y Serrano, 1858: págs. 255-256).

El examen de las estructuras narrativas de los relatos sobre la cueva de Hércules nos permite llegar a una serie de conclusiones. Desde el cronotopo primordial de la cueva, que hemos analizado en la primera parte del trabajo, esta famosa leyenda española es trazada sobre «un no lugar» e instalada en un tiempo a la vez mítico e histórico sin perder los recursos motrices básicos que el espacio facilita. Del espacio primordial toma el motivo del umbral prohibido, el tesoro custodiado e incluso el recuerdo de la presencia femenina; es evidente que la metáfora de la casa cerrada plantea de modo simbólico la 
violencia de Rodrigo contra Florinda. Desde estos fundamentos la leyenda avanza hacia la configuración de un cronotopo adecuado a la narración fantástica después de acarrear tópicos caballerescos. Dos movimientos van enlazándose en el discurrir de la leyenda por los cauces literarios y orales. De una parte la tendencia al desplazamiento y al incremento; baste un ejemplo: nacido de la raza de los titanes, Hércules es reduplicado en la figura del autómata gigantesco que impide el paso al héroe, con o sin compañía de los guardianes característicos. Los guardianes son multiplicados, como los seguros y cierres y el preciosismo de la cueva. De otro lado, la tradición legendaria que agrega nuevas topografías al suceso (cueva, torre, palacio, casa) va desmaterializando el espacio físico e intensificando el significado principal de la cueva: lugar de lo extraordinario. Desde este punto lo primordial conecta con los nudos espacio-temporales que indagan en la noción de lo extraordinario o sobrenatural tal como lo espacializan lo gótico-fantástico (el palacio, la cámara secreta, la torre, la cripta). El relato ha sido levantado desde la imaginación del espacio, no sobre la contemplación de su entidad física. Desde aquí, el itinerario de los personajes da primacía al ingreso en lo prohibido como movimiento principal. La aventura de Rodrigo es la trampa a donde le lleva su propia ambición; el tesoro oculto se revela simplemente como oráculo y maldición. Y en las narraciones más tardías asoma el dejo de la burla antiautoritaria.

\section{BIBLIOGRAFÍA}

S. A. «Historia de Alarabi» (1858) El Iris. Periódico semanal de Ciencias, Literatura y teatros. Año I, nº2, 9 de mayo, págs. 2-3.

A. L. (1850) «Estudios sobre viajes» San Sebastián y Biarritz, (Sobre La cueva del Amor), Museo de las familias, t. VIII, nº19, 25 de julio, pág. 455.

Amador de los Ríos, José (1845) Toledo pintoresco o descripción de sus más célebres monumentos. Madrid, Ignacio Boix.

A. L. (1851) «Cueva de Hércules. Las últimas excavaciones sobre la misma», Semanario pintoresco español, $\mathrm{n}^{\circ} 48,30$ de noviembre, págs. 382-383.

Bakhtine, M. (1978) Esthétique et théorie du roman. Paris, Tel-Gallimard, págs. $85-233$.

BALAGUER, Víctor (1851) Los frailes y sus conventos: Madrid-Barcelona, Vol.1: págs. 331-333.

BÉCQUER Gustavo Adolfo (2008), Leyendas. Ed.Pascual Izquierdo, Madrid, Cátedra, ed. 22, págs. 323-330.

BRosseau, Marc (1996) Des romans-géographes. Paris, L'Harmattan. 
CACHO BleCUA, J.M. (1995) «La cueva en los libros de caballería: la experiencia de los límites». Descensus ad inferus. La aventura de ultratumba de los héroes (de Homero a Goethe) ed. P. M. Piñero, Sevilla, Universidad, págs. 99-127.

Carvajal y Rueda, Froilán (1857) «La cueva de la judía», Semanario pintoresco español, $\mathrm{n}^{\circ}$ 23, 7 de junio, págs. 179-182.

CASTEllanos, B.S. (1837) «La torre encantada de Toledo», El Observatorio Pintoresco, $\mathrm{n}^{\circ} 17,30$ de agosto, págs. 133-135.

Cirlot, J.E. (2004) Diccionario de símbolos. Madrid. Siruela.

Collot, Michel (2007) «D’une modernité plurielle», Aline Bergé - Michel Collot [dir.], Paysage et modernité(s), Bruxelles, Éditions OUSIA (Recueil), págs. 15-27.

Collot, M. (2011), «Pour une géographie littéraire» LHT 8 (en ligne: http:// www.fabula.org/lht/8/index.php?id=242 consultada, 9-8-2013).

FeIjoo, Benito J. (1798) Theatro crítico, vol. VII, discurso VII, Madrid. por Andrés Ortega.

Franciosini, Lorenzo (1626) Diálogos apacibles. Sarzina.

FrANK, M. C. (2009). «Die Literaturwissenschaften und der spatial turn: Ansätze bei Jurij Lotman und Michail Bachtin». W. Hallet et B. Neumann (dirs.). Raum und Bewegung in der Literatur. Die Literaturwissenschaften und der Spatial Turn. Bielefeld: Transcript Verlag. 53-80.

GARCía MARTín, Francisco (2008), La Comisión de Monumentos de Toledo (18361875), Editorial Ledoria.

García de Diego, J.A., (1974) «La cueva de Hércules», Revista de Obras Públicas, 121, n³114: págs. 683-700.

García Tejero, Alfonso (1856) El Romancero histórico. Vidas de Españoles célebres. Madrid, Francisco Abienzo, Episodio en Pelayo. Año 718. Siglo VIII, Romance I, pág. 16.

HAGgerty KRAPPE, Alexander (1924), «La Légende de la Maison Fermée de Tolede», Bulletin Hispanique vol. 26, no 26-4; págs. 305-311.

IBO AlfARO, Manuel. (1859) La mora encantada o la bandera del amor. Impr. á cargo de Manuel Gomez.

IRVING, George Washington, (1836) Legends of the conquest of Spain, London. John Murray.

IRVING, George Washington (1845) «El Rodrigo recibe una embajada extraordinaria», La Crónica (Madrid), n²8, 13 de abril, pág.219 e «Historia de la cueva encantada y maravillosa», págs. 219-222.

IRVING, George Washington (1849) «La cueva de Hércules», La Esperanza, nº1364, 15 febrero pág. 3 y no 1349, 19 de febrero, pág. 4 .

IRVING, George Washington (1862) «La torre maravillosa. Leyenda toledana de W. Irving»; La Luz, (Barcelona), n. ${ }^{\circ}$ 58, 7 de diciembre pág. 464; nº 5914 de diciembre, págs. 471-471 y nº 60, 28 de diciembre págs. 479-480.

Anales, 25, 2013, pp. 397-427 
JOUVE, Vincent (1997) «Espace et lectura: la fonction des lieux dans la construction du sens», Cahiers de narratologie, no 8, págs. 177-191.

LAHAIE, Christiane (2008) «Entre géographie et littérature : la question du lieu et de la mimèsis». Cahiers de géographie du Québec 52 (147) (Diciembre-439-451)

LÉVY, B. (2006) «Géographie et littérature. Une synthèse historique». Le Globe. Revue genevoise de littérature, tome 146, Genève, 25-52.

Lista, Alberto, (1844) «Leyendas españolas de José Joaquín de Mora», Ensayos literarios y críticos, vol. I art.1. Calvo Rubio.

Madoz, Pascual (1840) Diccionario Geográfico, P. Madoz y L. Sagasti, vol. 14, pág. 832.

MAGÁN, Ángel, (1851) «Antigüedades. La cueva de Hércules», no 2731, El Heraldo, 13 de abril, pág. 3.

MAGÁN, Ángel, (1851a) Varios. El Heraldo, n²806, 5 julio, pág. 3.

MAGán, Nicolás (1840) «Cueva de Hércules y palacio encantado de Toledo», Semanario Pintoresco Español, t. II, nº 1,29 de marzo, no 1, págs. 100-101.

MARTín GAMERO, Antonio (1862) Historia de la ciudad de Toledo, sus claros varones y monumentos. Imp. de Severiano López Fando.

MARTínez DE LA Rosa, Francisco (1844) Isabel de Solís, Baudry, Librería Europea, págs. 227-231.

Mellado, Fernando (1866) «La cueva del lagarto. Leyenda de la Edad Media». Museo de las Familias, 1 de enero. págs. 10-18.

Mellado, Fernando (1870) «La cueva de la Mora», Museo de las Familias, t.II, 1 de abril, págs. 89-90; 116-119; 148-151.

MirALLES, Enrique (2008) «De las leyendas regionalistas al cuento regional», en Monserrat Amores, Estudios sobre el cuento español del siglo XIX. Vigo, Academia del Hispanismo, págs. 129 y ss.

Mellado, Francisco de Paula (1849), Recuerdos de un viage [sic] por España, Volumen 3, pág. 86.

MENÉndez PidAl, Ramón (1924) El rey Rodrigo en la Literatura (Revista de la Academia Española) abril.

MENÉNDEZ PIDAL, Juan (1905) Leyendas del último rey godo: don Rodrigo y la Caba, RABM, febrero, $\mathrm{n}^{\circ} 2$.

MorA, Juan de Dios (1852) Florinda o la Caba, Madrid, Repullés, 2. Edición. cp. XXII.

NePveu, Pierre (2005), Lectures des lieux, Montréal, Boréal.

Palacio, Manuel de (1857) «La cueva de Zampoña. Tradición», Museo Universal, I, no 6, 31 de marzo, págs. 46-47.

PONZ, Antonio (1787) Viaje de España. Madrid, Viuda de Ibarra.

PiATTI, Barbara (2009). «Mapping Literature: Toward a Geography of Fiction». ftp://cartography.ch/pub/pub_pdf/2009_Piatti_Geography_of_Fiction.pdf 
RoJAs, Trinidad de (1861) «La cueva de Menga», Museo Universal, no 37, 15 de septiembre, págs. 295-296.

Ruiz DE LA PuerTa (1977) La cueva de Hércules y el Palacio encantado de Toledo, Madrid, Editora Nacional.

RYAN, M.-L (2009) «Space». Handbook of Narratology. P. Hühn, J. Pier, W. Schmid et J. Schönert (dirs.). Berlín; New York: Walter de Gruyter, 420-433. (http:// www.lhn.unihamburg. (Consultado 12 de mayo 2013).

SiXTO PARRO, Ramón (1857) Toledo en la mano, ó, descripción histórico-artística (tomo I y II) Toledo, impr. de S. López Fando.

Fecha de recepción: 10/07/2013

Fecha de aceptación: 02/09/2013 